text of Bulletin 9 of the Forestry Commission by Prof. J. W. Munro, which is now out of print. The new bulletin, which is a revision and amplification of its predecessor, has been written by Dr. R. C. Fisher in consultation with Prof. Munro and includes the results of recent investigation. The longhorn and pinhole borers are essentially forest insects: they attack recently felled timber, but abandon it during the drying and seasoning. The powder-post and furniture beetles are enemies of seasoned woods, the former abounding in timber yards and the latter attacking antique furniture and the structural timbers of old buildings. The losses occasioned by these different classes of beetles are often very great, and the present bulletin gives a clear and wellillustrated account of how to avoid or reduce the damage by the adoption of preventive and remedial measures. The publication, which is Forest Products Research Bulletin No. 19, is obtainable from His Majesty's Stationery Office, or through any bookseller, price $1 s .6 d$. net.

\section{Evolution of Weapon Types and Design}

IN the Journal of the Franklin Institute of October, Brigadier-General Earl MeFarland, of the United States, has published a paper on the trend in weapon types and design. $\mathrm{He}$ first gives a sketch of the story of man's effort to adapt scientific principles to self-defence. Each of the great civilizations of history developed something new in the art of warfare. The epoch-making invention of gunpowder by the Chinese is placed first in the list. The period since the Napoleonic wars has seen the introduction of steel and its application to gun manufacture and projectiles. The development of chemistry has led to the manufacture of propellants and explosives exceeding by many times the effectiveness of the cruder preparations of a century ago. The development of military weapons during the last three generations has been greater than during the entire previous period of recorded history. The invention of the petrol engine had a revolutionary effect vastly increasing both the tactical and strategic mobility on the ground and in the air.

The United States Congress in 1794 passed an Act which provided for the establishment of a system of Government-owned shops for the manufacture of muskets. At the Springfield Armory, Massachusetts, the musket or rifle has been produced continuously for 144 years. The Frankford Arsenal, organized only twenty years later than Springfield Armory, has carried on without interruption, in war and in peace, the manufacture of ball, armour-piercing and tracer ammunition for rifles and machine-guns ; it is now manufacturing the mechanical time fuse. American troops are being armed with the semiautomatic shoulder rifle, officially known as U.S. Rifle, Calibre $\cdot 30 \mathrm{Ml}$., but often referred to as the Garand rifle, from J. C. Garand, an ordnance engineer of Springfield Armory, who was mainly responsible for its design and development. The trend in rifle design is toward the type which demands the least time of training and which gives the greatest number of aimed shots per minute with the minimum fatigue to the firer. At the present moment, a contest is going on between the anti-tank gun and tank armour. The gun is sure to win in the long run.

\section{Interior Lighting and Decoration by Fluorescence}

New effects in interior decoration have been obtained recently by using fluorescent paints and ultra-violet lamps. In the Hawaii Theatre opened in the early summer in Hollywood the whole of the walls and ceilings have been covered with fluorescent paint. When cinema pictures are shown the ultraviolet lamps are switched on, but no other illumination is used. The whole auditorium then seems to be bathed in 'shadowless moonlight' and the walls appear to have receded. The audience has the impression of sitting under a deeply luminous blue Hawaiian night sky with brightly glowing stars. In earlier attempts at interior decoration by fluorescence, blues and greens preponderated to give only a limited range of colours. A sufficient number of paints, twelve in all, has now been developed so that landscapes ean be painted on the walls. A panel of Mount Manua Loa spouting fire and smoke gives the impression of many miles in distance. The fluorescent materials can be had as either solid paints or trans. parent varnishes. White fluorescence is obtained by applying two complementary colours, such as a red and a green, so that at a distance from the surface the light mixes well enough to give an effect of white light. The transparent varnishes are invisible in ordinary light.

Advertising signs have been made to give one picture in natural light and a second picture in filtered ultra-violet-'black light'. Carpets have also been impregnated with fluorescent substances. Details of all the products can be had from Conti-Glo Paint, Continental Lithograph Corp., 952 East 72nd Street, Cleveland, Ohio. The literature supplied is concerned with the decorative and third-dimensional effects. As, however, the use of ultra-violet light is an essential part of the scheme it would appear that, by extending the range of the ultra-violet sources, air sterilization could also be combined with the new decorative effects. In hospitals at night, where lowlevel illumination is needed, the patients could have the beneficial effects of air sterilization together with rest under a "deeply luminous blue Hawaiian night sky".

\section{Testing Steel Rails}

A DESCRIPTION is given in the Electrical Review of November 22 of the method developed by Sperry Products, Inc., Hoboken, New Jersey, U.S.A., for examining steel running rails of railways in situ for internal defects. A recording car is used, and operation is based on the fact that any internal discontinuity in a metal bar creates an area of high resistance to the flow of direct current; consequently a difference of potential will occur at the site of the internal flaw. Indicating currents are conveyed to the track rails by brush holders attached behind the front bogie and underneath the frame of the rear bogie of the 
coach. A current of about 1,500 amp. up to 8 volts is injected for pre-energizing the rails to ensure uniformity of molecular arrangement prior to the introduction of the detecting current just in front of the two pairs of searching coils. This precaution is necessary because running rails are generally magnetized by the normal effect of the earth's field, augmented by vibration due to the pounding of passing train wheels.

The magnetic poles strongly formed in this way are of two kinds; the effects of the superficial ones on the surface of the rail can be avoided by the use of suitable brush gear for conveying the test current to the rails, while those within the railhead can be overcome by raising the detective current density to 275 amp. per sq. in., which means feeding 4,000 amp. to each rail at up to 4 volts. The testing currents are furnished by a petrol engine with gear-box and multiple belt pulley which drives the main current $(8,000 \mathrm{amp}$ ) and auxiliary (pre-energizing) generators and a 200 -volt exciter mounted together in the car. The recording tape moves at $0.025 \mathrm{in}$. per $\mathrm{ft}$. of car travel; the recording car travels at seven miles per hour when fault detecting. It is reported that in seven months this year 597,000 miles of track, tested in this way, revealed 304,000 defective rails.

\section{Movable Electric Generating Stations}

The Commissariat of the Building Industry of the U.S.S.R. is constructing 1,000 movable electric generating stations for use in timber camps and on railway construction jobs. The movable generating stations will be of various capacities, beginning with the smallest, of $2.5 \mathrm{kw}$, which will be used by railway maintenance men. Generators of this capacity will be installed on hand-carts and moved about from place to place as required. Electric generating stations of $30 \mathrm{kw}$. capacity will be fitted on the running-boards of automobiles and worked by the motor engine. A novel feature of the electric power stations of $50 \mathrm{kw}$. capacity will be a gas generator, instead of the ordinary Diesel engine, which will effect a considerable saving of fuel.

\section{New Seismographs for Boulder Dam}

AN ambitious, though necessary, seismological programme is being undertaken in the neighbourhood of the Great Boulder Dam (Earthquake Notes, 22, Nos. 1 and 2, September 1940). A Wood-Anderson seismograph has been operating for several years at Boulder City, and two Neumann-Labarre vibration meters are temporarily installed at Overton, Nevada. The seismograph buildings at Pierce Ferry on Lake Mead are almost ready to house the temporary Coast and Geodetic Survey vibration meters. The construction of permanent Benioff instruments recording on $35-\mathrm{mm}$. motion picture film for all three stations is nearing completion. Four records, two horizontal, one vertical and one 'time record', will be made simultaneously on one drum. The 'time record' will be a film on which radio time signals will be recorded at regutar intervals several times each day in addition to the regular chronometer time marks. Through the use of a reading microscope with two-way micrometer control, it will be possible to read time from the record to the nearest hundredth of a second and to measure amplitude to corresponding precision. Another feature of the seismographs is a second vertical seismometer used to control relays for intensifying the recording light at times of recording strong seismic disturbances.

\section{Earthquake in Chile}

ON the basis of instrumental reports from fourteen seismographic observatories, the United States Coast and Geodetic Survey, in co-operation with Science Service and the Jesuit Seismological Association, has determined the epicentre of the earthquake of October 11, 1940, to be provisionally at latitude $45^{\circ} \mathrm{S}$., longitude $73^{\circ} \mathrm{W}$. This is on the mainland of Chile opposite the Chanos Archipelago and north of Taitao Peninsula. It has been the scene of many small earthquakes and earth tremors in the past.

\section{Announcements}

Prof. Hugo Iltis, formerly director of the Mendel Museum in Brno, has been appointed professor of biology in Mary Washington College, Fredericksburg, Virginia.

Prof. Th. Dobzhansky, formerly professor of genetics in the California Institute of Technology, Pasadena, has been appointed professor of zoology in Columbia University, New York.

DR. A. C. SмIтH, formerly associate curator of the Herbarium, New York Botanical Garden, has been appointed curator of the Herbarium of the Arnold Arboretum, of Harvard University.

THE following appointments in the Colonial Service have recently been made: J. E. Hardy, chief plant protection officer, Palestine; J. K. H. Wilde, veterinary research officer, Tanganyika.

At a Congregation of the Senate of the University of Cambridge on December 9, degrees of M.A. honoris causa were conferred on Prof. A. M. Carr-Saunders, director of the London School of Economics and Political Science; Prof. F. L. Hopwood, professor of physics in the University of London (St. Bartholomew's Hospital Medical College); and Prof. A. E. Richardson, professor of architecture in University College, London.

The British Museum (Natural History) has recently published three additions to the series of "Economic Leaflets". These are No. 4, "Psocids, Book Lice, Dust Lice, etc." ; No. 5, "Crickets" ; and No. 6, "Plaster Beetles". Each type of insect dealt with is clearly illustrated and an account is given of its habits, the injuries that it may cause and the best means of controlling it. The leaflets are sold at the British Museum, Cromwell Road, London, S.W.7, price $1 d$. each for Nos. 5 and 6 , and $\frac{1}{2} d$. for No. 4 . 